\title{
ANALISIS PERBANDINGAN RETURN DAN RISK (STUDI PADA SAHAM SYARIAH DAN SAHAM KONVENSIONAL LQ45 PERIODE (2012-2016)
}

\author{
Muammar Khaddafi ${ }^{1}$, Ferdiansyah ${ }^{2}$ \\ ${ }^{1,2}$ Prodi Akuntansi Fakultas Ekonomi dan Bisnis Universitas Malikussaleh Lhokseumawe \\ khaddafi@unimal.ac.id
}

\begin{abstract}
This study aims to analyze the comparison of Return and Risk study in syariah Stocks and convensional stocks LQ45 Indeks in companies listed on the Indonesia Stock Exchange by using Purposive Sampling by comparing the rate of return and risk of these shares. The method used is the Independent Sample T-test and comparing the performance of mutual funds using the Jensen Test during the period 2012-2016, the results showed that there was no significant difference between the rate of return and risk of the Syariah Stock and Conventional Stock Index during the 2012-2016 period.
\end{abstract}

Keywords: Purposive Sampling, Return, Risk, Independent Sample T-test, Jensen Test.

\section{PENDAHULUAN}

Berkembangnya sistem Perekonomian Islam di Indonesia menjadi fenomena yang tidak terlepas dari tuntutan masyarakat Indonesia yang mayoritas Islam akan kegiatan ekonomi yang halal dan bebas dari riba .dan juga Bertambahnya kebutuhan manusia, terlebih diera modern saat ini, membuat aktivitas ekonomi semakin meningkat, untuk itu masyarakat modern mulai merambah dunia investasi dalam rangka memenuhi kebutuhan hidupnya. Banyaknya kegiatan pasar modal merupakan faktor pendorong munculnya alternatif produk investasi yang ditawarkan.

Kinerja reksadana jenis saham diukur dengan melihat tingkat pengembalian dan risiko dari portofolio itu sendiri karena Seorang investor mengharapkan tingkat pengembalian yang tinggi dari investasi yang dilakukannya. Namun, untuk mendapatkan return yang tinggi, investor menghadapi risiko yang tinggi pula. Artinya semakin tinggi return yang diharapkan semakin tinggi risiko investasi sehingga kedua variabel ini menjadi aspek pertimbanagn penting dalam keputusan investasi

\section{LANDASAN TEORI}

\section{Definisi Reksadana}

Menurut Undang-Undang Pasar Modal no.8 Tahun 1995, pasal 1 ayat (27) disebutkan bahwa Reksadana adalah wadah yang digunakan untuk menghimpun dana masyarakat pemodal untuk selanjutnya diinvestasikan dalam portofolio efek oleh Manajer Investasi yang telah mendapat izin dari Bapepam.

\section{Risiko (Risk)}

Definisi risiko menurut Kamus Besar Bahasa Indonesia (KBBI) adalah akibat yang kurang menyenangkan (merugikan, membahayakan) dari suatu perbuatan atau tindakan. Menurut Arthur J. Keown (2000), risiko adalah prospek suatu hasil yang tidak disukai (operasional sebagai deviasi standar). Definisi risiko menurut Hanafi (2006) risiko merupakan besarnya penyimpangan antara tingkat pengembalian yang diharapkan (expected return-ER) dengan tingkat pengembalian aktual (actual return).

\section{Tingkat Pengembalian (Return)}

Menurut Fahmi (2014:358), Return adalah keuntungan yang diperoleh perusahaan, individu dan institusi dari hasil kebijakan investasi yang dilakukannya. Sedangkan Bodie et., all (2011) mendefinisikan return sebagai penjumlahan sederhana pendapatan yang diperoleh dari setiap. Dengan demikian, dapat dikatakan bahwa return merupakan tingkat pengembalian yang diperoleh atas investasi yang dilakukan.

\section{Kerangka Penelitian}

Gambar 1 Kerangka konseptual

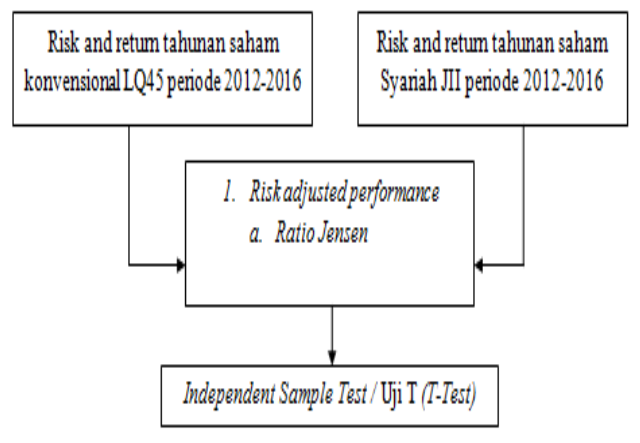


Sumber : Mulya Riyady Esha, Mohammad Heykal dan Titik Indrawati (2014) dan Lidia Desiana dan Isnurhadi (2012)

\section{METODOLOGI PENELITIAN Lokasi dan Objek Penelitian}

Penelitian ini merupakan studi komperatif tentang tingkat pengembaliaN (return) dan risiko (risk) dari saham syariah dan konvensional selama periode tahun 2012 - 2016 yang terdaftar di Bursa Efek Indonesia.

\section{Populasi}

Populasi dalam penelitian ini adalah seluruh perusahaan yang masuk dalam indeks LQ-45 dan JII di Bursa Efek Indonesia pada periode 2012-2016 yaitu 655 harga Saham dan jumlah sampel untuk LQ45 adalah 130 harga saham dan JII 75 Harga saham

\section{Metode Analisis \\ .Uji Independent Samples T-Test}

Tabel 1

Independent Samples Test Return

\begin{tabular}{|c|c|c|c|c|c|c|}
\hline & \multicolumn{5}{|c|}{ t-test for Equality of Means } \\
\hline & & $\mathrm{T}$ & $\mathrm{df}$ & $\begin{array}{l}\text { Sig. (2- } \\
\text { tailed) }\end{array}$ & $\begin{array}{c}\text { Mean } \\
\text { Difference }\end{array}$ & $\begin{array}{c}\text { Std. Error } \\
\text { Difference }\end{array}$ \\
\hline \multirow[t]{2}{*}{$\begin{array}{l}\text { Return } \\
\text { Saham }\end{array}$} & $\begin{array}{l}\text { Equal } \\
\text { variances } \\
\text { assumed }\end{array}$ & -.237 & 39 & .814 & -.0076272 & .0322170 \\
\hline & $\begin{array}{l}\text { Equal } \\
\text { variances not } \\
\text { assumed }\end{array}$ & -.225 & 25.169 & .824 & -.0076272 & .0338729 \\
\hline
\end{tabular}

Dari tabel diatas dapat dilihat bahwa nilai $\mathrm{F}=1.691(\mathrm{p}=0,201)$ karena $\mathrm{p}$ diatas 0,05 maka dapat dikatakan bahwa tidak ada perbedaan varians pada data Return LQ45 dan Return JII (data equal/homogen) maka hal ini menunjukkan bahwa Uji Independent T-test sesuai digunakan untuk menguji perbedaan dari data diatas.

Dari tabel diatas terlihat bahwa hasil dari Uji independent T-test menunjukkan nilai $\operatorname{Sig}(2$ tailed) sebesar 0,814 (Sig>0,05) maka dapat diambil keputusan sesuai dengan dasar pengambilan keputusan Uji Independent T-test bahwa Ho diterima dan Ha ditolak yang artinya tidak terdapat perbedaan signifikan antara Return saham Indeks LQ45 dan Return saham Indeks JII. tetapi jika dilihat dari ratarata hitung(mean) dapat disimpulkan bahwa Return saham Indeks JII lebih tinggi dibandingkan dengan Return saham Indeks LQ45 (0,110673 > 0,103046) walaupun selisihnya tidak signifikan.

\begin{tabular}{|ll|r|r|r|}
\hline & Indeks Harga & \multicolumn{3}{|c|}{ Shapiro-Wilk } \\
\cline { 3 - 5 } & Saham & Statistic & \multicolumn{1}{c|}{ df } & \multicolumn{1}{c|}{ Sig. } \\
\hline Return & Indeks LQ45 & .947 & 26 & .202 \\
Saham & Indeks JII & .909 & 15 & .129 \\
\hline
\end{tabular}

Tabel 2

Independent Samples Test Return

\begin{tabular}{|c|c|c|c|c|c|c|}
\hline & \multicolumn{5}{|c|}{ t-test for Equality of Means } \\
\hline & & $\mathrm{T}$ & $\mathrm{df}$ & $\begin{array}{l}\text { Sig. (2- } \\
\text { tailed) }\end{array}$ & $\begin{array}{c}\text { Mean } \\
\text { Difference }\end{array}$ & $\begin{array}{l}\text { Std. Error } \\
\text { Difference }\end{array}$ \\
\hline Risk & Equal variances assumed & .276 & 39 & .784 & .0213985 & .0775636 \\
\hline Saham & $\begin{array}{l}\text { Equal variances not } \\
\text { assumed }\end{array}$ & .270 & 27.494 & .789 & .0213985 & .0792328 \\
\hline
\end{tabular}

Dari tabel diatas dapat dilihat bahwa nilai $\mathrm{F}=0,002(\mathrm{p}=0,968)$ karena $\mathrm{p}$ diatas 0,05 maka dapat dikatakan bahwa tidak ada perbedaan varians pada data Risk LQ45 dan Risk JII (data equal/homogen) maka hal ini menunjukkan bahwa Uji Independent Ttest sesuai digunakan untuk menguji perbedaan dari data diatas.

Dari tabel diatas terlihat bahwa hasil dari Uji independent T-test menunjukkan nilai $\operatorname{Sig}(2$ tailed) sebesar 0,784 (Sig>0,05) maka dapat diambil keputusan sesuai dengan dasar pengambilan keputusan Uji Independent T-test bahwa Ho diterima dan Ha ditolak yang artinya tidak terdapat perbedaan signifikan antara Risk saham Indeks LQ45 dan Risk saham Indeks JII. tetapi jika dilihat dari rata-rata hitung(mean) dapat disimpulkan bahwa Risk saham Indeks LQ45 lebih Tinggi dibandingkan dengan Risk saham Indeks LQ45 (0, .320338> 0,298940) walaupun selisihnya tidak signifikan.

\section{Hasil Uji Kinerja Jensen LQ45 dan JII}

Hasil kinerja dari Indeks LQ45 dan JII menurut Uji Jensen dapat Dilihat bahwa Rata-rata dari Uji jensen JII lebih Tinggi dari Rata-rata Uji jensen LQ45 (0,0633 > 0,0574) yang artinya Indeks JII mempunyai kinerja lebih baik daripada Indeks LQ45 selama \% tahun pengamatan (2012-2016).

Hal ini bisa dikarenakan syarat dan kriteria yang ditentukan untuk bergabung dengan indeks JII yang bisa dikatakan cukup ketat sehingga saham perbankan yang tidak memenuhi kriteria syariah yang telah ditetapkan tidak termasuk kedalam indeks JII , dimana sektor perbankan sangat sensitif dengan isu perekonomian yang sangat mudah terkena dampak dari lemahnya nilai rupiah dan hal lainnya. 
Pembahasan Hasil Penelitian

Perbedaan Resiko dan Tingkat Pengembalian Antara Jakarta Islamic Indeks (JII) dan LQ45 pada Bursa Efek Indonesia Periode 2012-2016

Berdasarkan Hasil uji pada tabel 4.10 dan 4.12 merupakan rata-rata Return dari setiap perusahaan selama 5 tahun (2012-2016) yang diamati dari indeks saham LQ45 dan Indeks JII Hal yang menyebabkan tidak terdapat perbedaan yang signifikan bisa dikarenakan saham perusahaan yang terdaftar di indeks LQ45 juga terdaftar di Indeks saham JII karena perusahaan tersebut telah memenuhi kriteria dan syarat untuk bergabung dengan indeks LQ45 dan Indeks JII yang menyebabkan perolehan Return yang berkontribusi dalam rata-rata indeks masing-masing juga hampir sama tetapi dengan adanya perusahaan yang hanya terdaftar di salah satu indeks karena perusahaan yang menjadi sampel ada yang tidak memenuhi kriteria dan syarat untuk bergabung dengan Indeks saham JII akan menghasilkan Return yang berbeda.dan dari hasil diatas dapat dilihat bahwa tidak terdapat perbedaan yang signifikan antara Return Indeks LQ45 dan Return Indeks JII. tetapi Indeks JII memiliki Return yang lebih tinggi dibandingkan Return dari Indeks LQ45.

Hasil uji ini merupakan rata-rata Risk dari setiap perusahaan selama 5 tahun (2012-2016) yang diamati dari indeks saham LQ45 dan Indeks JII Hal yang menyebabkan tidak terdapat perbedaan yang signifikan bisa dikarenakan saham perusahaan yang terdaftar di indeks LQ45 juga terdaftar di Indeks saham JII karena perusahaan tersebut telah memenuhi kriteria dan syarat untuk bergabung dengan indeks LQ45 dan Indeks JII yang menyebabkan perolehan Risk yang berkontribusi dalam rata-rata indeks masing-masing juga hampir sama tetapi dengan adanya perusahaan yang hanya terdaftar di salah satu indeks karena perusahaan yang menjadi sampel ada yang tidak memenuhi kriteria dan syarat untuk bergabung dengan Indeks saham JII akan menghasilkan Return yang berbeda.dan dari hasil diatas dapat dilihat bahwa tidak terdapat perbedaan yang signifikan antara Risk Indeks LQ45 dan Risk Indeks JII tetapi Indeks LQ45 memiliki Risk yang lebih tinggi dibandingkan Risk dari Indeks JII.

Dari kedua uji Independent Sample T-test dapat dilihat bahwa tidak terdapat perbedaan yang signifikan antara Return dan Risk dari kedua Indeks tersebut dan perbedaan yang terdapat hanyalah perbedaan kecil pada rata-rata kedua Ideks tersebut hal ini telah dibahas diatas mengapa tidak terjadi perbedaan yang sgnifikan diantara kedua Indeks tersebut selama periode 2012-2016 yang diamati

\section{PENUTUP}

\section{Kesimpulan}

1. Tidak terdapat perbedaan yang signifikan antara Return saham Indeks LQ45 (konvensional) dan Return saham Indeks JII (syariah) selama periode 2012-2016.

2. Tidak terdapat perbedaan yang signifikan antara Risk saham Indeks LQ45 (konvensional) dan Risk saham Indeks JII(syariah) selama periode 20122016.

\section{DAFTAR PUSTAKA}

Adam Suseno, dkk, 2012, Buku : Penggunaan Quantum Gis Dalam Sistem Informasi Geografis, Bogor.

Alwi Z Iskandar. 2003. Pasar Modal Teori dan Aplikasi, Edisi Pertama. Jakarta:Penerbit Yayasan Pancur Siwah.

Anoraga, Pandji dan Piji Pakarti. 2006. Pengantar Pasar Modal. Rineka Cipta: Jakarta

Arikunto, Suharsimi. 2006. Prosedur Penelitian Suatu Pendekatan Praktik. Jakarta: Rineka Cipta.

Arthur J. Keown, David F. Scott, Jr., John D. Martin, J. William Petty. 2001.Dasar-dasar Manajemen Keuangan Edisi Ketujuh. Terjemahan Chaerul.D. Djakman, SE Akt, MBA. Penerbit salemba Empat, Jakarta.

Bambang Riyanto, 1997, Dasar-dasar Pembelanjaan Perusahaan, Edisi 4. BPFE, Yogyakarta.

Bodie, Z., Kane, A., \& Marcus, AJ. (2011). Investments and portofolio Management. Global Edition. New York : The McGrawHill Companies, Inc.

Brigham, et al. 1999. Financial management Theory and Pactice. The Dryden Press. Orlando. hal 192.

Burhan Nurgiyantoro dkk. 2004. Statistik Terapan untuk Penelitian Ilmu-ilmu Sosial. Yogyakarta. Gadjah Mada University Press.

Corrado, C. J., dan B. D. Jordan. 2000. Fundamentals of Investment Analysis, 4th Ed. Singapore: Mc Graw-Hill.

Darmadji dan Fakhruddin . 2012. Pasar Modal Di Indonesia Edisi Ketiga, Jakarta: Selemba Empat 
Darmadji T. dan Hendy M. Fakhruddin. 2001. Pasar Modal Di Indonesia. Jakarta: Salemba Empat.

Desiana, Lidia dan Isnurhadi . 2012. "Perbandingan Kinerja Reksa Dana Saham Konvensional dengan Reksa Dana Saham Syariah Di Bursa Efek Indonesia". Jurnal Manajemen dan Bisnis, Vol. 10, No.20, Universitas Sriwijaya

Esha, Mulya Riyady , dkk (2014). “Analisis Perbandingan Reksa Dan Saham Syariah dengan Reksa dana Konvensional periode 2009-2012" Binus Bussiness Review Vol.5 No.1. Universitas Binus

Fahmi, Irfan dan Yofi Laviandi Hadi.2012.Teori Portofolio dan Analisis Investasi, Bandung: Alfabeta.

Fahmi, Irham. 2014. Bank dan Lembaga Keuangan Lainnya. Cet. I. Bandung: Alfabeta.

Fahmi, Irham. 2014. Pengantar Perbankan dan Teori Aplikasi. Cet. I. Bandung: Alfabeta.

Fakhruddin,M. 2001. Perangkat dan Model Analisis Investasi di Pasar Modal Jakarta:Gramedia.

Fatra, O. S. (2014). Analisis Perbandingan Kinerja Reksadana Konvensional dengan Reksadana Syariah di Indonesia., Skripsi. Jember : FE UNEJ.

Fatwa Dewan Syari'ah Nasional Nomor 40/DSNMUI/X/2002

Ghozali, Imam . 2013 • Aplikasi Analisis Multivariate dengan Program SPSS.Edisi Ketujuh . Semarang:Badan Penerbit Universitas Diponogoro

Gumanti dan Elok Sri Utami. (2002). Bentuk Pasar Efisien dan Pengujiannya. Jurnal Akuntansi dan Keuangan. Vol 4. No. 1. Hal. 54-58.

Hamzah, Amal dan Agustinur Yohanes. (2014). "Analisis Perbandingan Kinerja Reksa Dana Syariah dengan Reksa Dana Konvensional jenis Saham pada periode 2008-2012" Jurnal MIX, Volume IV, No. 3, Universitas Mercubuana Jakarta.

Hartono, Jogiyanto. (2003). Teori Portofollio dan Analisis Investasi, Edisi kelima. Yogyakarta: BPEE

Horne, J. C. V., dan J. M. Wachoviz. 1998. Fundamental of Financial Management, 8th Ed. New Jersey: Prentice Hall International

Huda, Nurul dan Mustafa Edwin Nasution , (2007), Investasi Pada Pasar Modal Syariah, Prenada Media Grup.

Husnan Suad. 2001. Dasar-Dasar Teori Portofolio dan Analisis Sekuritas, Edisi ketiga, Cetakan Kedua, UPP AMP YKPN

Imam Ghozali. 2011. Aplikasi Analisis Multivariate Dengan Program IBM SPSS 19. Edisi 5. Semarang : Badan Penerbit Universitas Diponegoro.

Indriantoro, nurdan Supomo, bambang (1999).Metodologi Penelitian Bisnis Untuk Akuntansi \& Manajemen. Yogyakarta : Penerbit BPFE.

Jogiyanto. (2007). Teori Portofolio dan Analisis Investasi. Edisi Kelima. Yogyakarta: BPFE

Jogiyanto. 2003, Teori Portofolio dan Analisis Investasi, Edisi 3, Universitas Gadjah Mada, Yogyakarta

Jogiyanto. 2010. Teori Portofolio dan Analisis Investasi. Edisi Ketujuh. Yogyakarta: BPFE-Yogyakarta.

Jones, Charles P. 2000. Investment: Analysis and Management Seventh Edition, John Willey and Sonc.Inc

Kartini. (2011). “Analisis Perbandingan Kinerja Reksa Dana Konvesional dan Reksa Dana Syariah".

Kuncoro, M. (2009). Metode Riset untuk Bisnis \& Ekonomi Edisi 3. Jakarta: PT. Glora Aksara Pratama.

Lailiyah, Elliv Hidayatul, Suhadak dan Sri Sulasmiyati (2016) "Analisis Perbandingan Kinerja Reksa Dana Syariah dan Reksa Dana Konvensional (Studi pada Reksa Dana yang Terdaftar di Otoritas Jasa Keuangan Periode 2012-2016) " Jurnal Administrasi Bisnis Vol 35 No.2, Universitas Brawijaya Malang.

Loosemore, Raftery, Reilly, Higgon, (2006). Risk Management in Projects.

Majid, M.Shabri Abd dan Cut Windaswari (2015). "Analisis Return dan Kalender Anomali: Studi Komparatif Antara Saham Syariah dan Konvensional Di Indonesia". Universitas Syiah Kuala. 
Margono. 2004. Metodologi Penelitian Pendidikan. Jakarta: PT Rineka Cipta

Martalena dan Malinda . 2011. Pengantar Pasar Modal Edisi Pertama, Yogyakarta: Andi.

Mishkin, F. S. 2001. The Economic of Money Banking, and Financial Markets. Sixth Edition. Addison Wesley Longman: Columbia University,Columbia.

Muhammad Firdaus. 2005. Mengatasi Masalah Dengan Pegadaian Syariah. Jakarta: Renaisan

Mukmin, Amirul dan Firmansyah. (2015). “Analisis Perbandingan Volatilitas Indeks Harga Saham IHSG dan JII".Vol.3.No.1. Sekolah Tinggi Ekonomi Islam SEBI,Depok, Jawa Barat.

Mulyadi. 2001. Sistem Akuntansi Edisi Tiga. Jakarta : Salemba Empat.

Murdifin Haming dan Salam Basalamah, 2003. Studi Kelayakan Investasi : Proyek dan Bisnis . Jakarta : PPM.

Putry, Galishia, Iman Sugema dan Deni Lubis. (2013). "Analisis Perbandingan Excess Return Jakarta Islamic Index dan Indeks Harga Saham Gabungan ".Jurnal Al Muzara'ah Vol.2 No.2. Institut Pertanian Bogor.

Rahardjo , Sapto . 2003. Panduan Investasi Obligasi, Jakarta: PT Gramedia Pusaka Utama

Rosyida, Ajeng Gama dan Imron Mawardi. (2015). "Perbandingan Tingkat Pengembalian (Return) Risiko dan Koefisien Variasi pada Saham Syariah dan Non Syariah di Bursa efek Indonesia (BEI) periode 20112013" . JESTT Vol.2 No.4 Universitas Airlangga.

Sawidji Widoatmodjo. 2012. Cara Cepat Memulai Investasi Saham Panduan Bagi Pemula. Jakarta: PT Elex Media Komputindo.

Sharpe, William F et.al . 1995. Investment Fifth Edition. Prentice Hall: New Jersey

Sudarsono, Heri. 2012. Bank dan Lembaga Keuangan Syariah Edisi keempat, Yogjakarta: Ekonisia. 
Volume 5, Nomor 1, Februari 2017 